\section{'NuMex Chaco' Onion}

\author{
Christopher S. Cramer ${ }^{1}$ and Joe N. Corgan ${ }^{2}$ \\ Department of Agronomy and Horticulture, Box 30003, MSC 3Q, New Mexico \\ State University, Las Cruces, NM 88003-0003
}

Additional index words. Allium cepa, vegetable breeding, Phoma terrestris

The New Mexico Agricultural Experiment Station announces the naming and release of 'NuMex Chaco' onion (Allium cepa L.). 'NuMex Chaco' is a single-centered, bolting-resistant, pink-root-resistant, early maturing, short-day, yellow onion cultivar for fall seeding in southern New Mexico. It matures in late May when fall-seeded in Las Cruces, N.M. 'NuMex Chaco' produces a higher percentage of single-centered bulbs than any other fall-planted cultivar grown in southern New Mexico and is highly suited for onion ring processing.

\section{Origin}

'NuMex Chaco' originated from a cross between 'Texas Early Grano 502 PRR BR' and 'Southport White Globe'. 'Texas Grano 502 PRR BR' is a bolting-resistant selection from 'Texas Grano 502 PRR' (Corgan, 1984). 'Texas Grano 502 PRR' was a pink-rootresistant selection from 'Texas Grano 502' that may have been combined with a malesterile selection of 'Excel 986' (Havey and Bark, 1994). 'Texas Grano 502' was selected from 'New Mexico Early Grano', which originated from lines introduced from Spain labeled as 'Valencia Grano' (Garcia and Fite, 1931; Corgan, 1984). 'Texas Early Grano 502 PRR BR' is a short-day, yellow onion that matures early when fall-planted in southern New Mexico. 'Texas Early Grano 502 PRR BR' is grano-shaped and produces large bulbs that are low in pungency and in soluble solids, have soft flesh and few dry scales, and store for short periods of time (Hawthorn, 1944). 'Southport White Globe' originated from the onion growing district in Southport, Conn. (Magruder, 1941). It is an intermediate-day, white onion commonly grown in the northern United States for its firm to hard, medium-sized, slightly flattened to slightly oval-shaped bulbs that are high in soluble solids and pungency, and can be stored for long periods of time. 'Southport White Globe' is not grown in southern New Mexico.

The initial cross was made in 1980 by intercrossing the two parents in a common pollination cage, using honey bees as the pollen vector. Only seeds from 'Texas Early Grano 502 PRR BR' plants were collected and planted. Since 'Texas Early Grano 502

Received for publication 25 Sept. 2000. Accepted for publication 5 May 2001. This research was funded by the NMSU Agricultural Experiment Station and the New Mexico Dry Onion Commission. ${ }^{1}$ Assistant Professor of Horticulture.

${ }^{2}$ Professor Emeritus and José Fernandez Chair of Crop Production.
PRR' was confirmed to be entirely S cytoplasm (Havey and Bark, 1994), 'NuMex Chaco' possesses entirely S cytoplasm. The following year, white bulbs with good pink root resistance, bolting resistance, grano bulb shape, bulb firmness, and good white bulb scale color were selected in 1981 . Selection was done at field maturity from fall seeding near Las Cruces, N.M. The selections were made from fields that contained high inoculum levels of Phoma terrestris, causal organism of pink root. The selected bulbs were intercrossed and three additional selections in 1983,1985 , and 1987 were made for yellow bulbs, bolting resistance, pink root resistance, bulb shape, uniformity, and maturity using phenotypic recurrent selection. Yellow bulbs from the third selection were grouped to make sib-crosses among three bulbs. The resulting progeny were screened for segregaseedstalks by the total number of plants per plot. (completely infected roots). size to 1 ha. the center of the bulb. tion of yellow and white bulbs. Six families that produced only yellow bulbs were selected and recombined in 1989. In 1991, 1993, 1995, and 1997, selections were made using recurrent selection and each year's selections were intercrossed to form the next generation. The selection criteria were the same as mentioned previously except that the last three generations were also selected for the production of single growing points per bulb (single center).

Selection for bolting resistance was done from field plantings that possessed $70 \%$ or more plants with seedstalks. Seeds were planted on an early planting date (around 1 Sept.) to induce seedstalk production. This date is three to four weeks earlier than the earliest recommended planting date for fall-planted onions in southern New Mexico. Selection for pink root resistance was accomplished by planting selections in fields that were severely infested with $P$. terrestris. At bulb maturity, bulbs were rated for the incidence of pink root on their root system. Only bulbs that possessed a healthy root system with minimal symptoms of pink root were selected.

Selection for bulb shape was for a medium depth grano shape, and for a bulb that was more rounded, with less pronounced shoulders and taper than a typical grano shape. Selection for bulb shape uniformity was for

Table 1. Maturity date, percentage of seedstalks, pink root rating, percentage marketable yield, marketable yield, average bulb weight, and percentage of single centers of 'NuMex Chaco' as compared with 'Daybreak', 'Ibex', and 'NuMex Mesa' when tested at the Fabian Garcia Science Center, Las Cruces, N.M., during the 1997-98, 1998-99, and 1999-2000 growing seasons.

\begin{tabular}{|c|c|c|c|c|c|c|c|}
\hline Cultivar & $\begin{array}{c}\text { Maturity } \\
\text { date }^{z}\end{array}$ & $\begin{array}{c}\text { Seedstalks } \\
(\%)^{\mathrm{y}}\end{array}$ & $\begin{array}{l}\text { Pink } \\
\operatorname{root}^{\mathrm{x}}\end{array}$ & $\begin{array}{c}\text { Marketable } \\
\text { yield } \\
(\%)^{\mathrm{w}}\end{array}$ & $\begin{array}{c}\text { Marketable } \\
\text { yield } \\
\left(\mathrm{t} \cdot \mathrm{ha}^{-1}\right)^{\mathrm{v}}\end{array}$ & $\begin{array}{c}\text { Average } \\
\text { bulb wt } \\
(\mathrm{g})^{\mathrm{u}}\end{array}$ & $\begin{array}{c}\text { Single } \\
\text { centers } \\
(\%)^{\mathrm{t}}\end{array}$ \\
\hline \multicolumn{8}{|c|}{$1997-98$} \\
\hline NuMex Chaco & 22 May & 3.2 & 3.4 & 91 & 58.7 & 335 & --- \\
\hline Daybreak & 25 May & 18.0 & 2.8 & 92 & 62.9 & 277 & --- \\
\hline Ibex & 23 May & 5.3 & 4.1 & 91 & 71.8 & 267 & --- \\
\hline NuMex Mesa & 22 May & 2.5 & 2.8 & 93 & 62.9 & 305 & --- \\
\hline Mean & 23 May & 7.3 & 3.2 & 92 & 66.1 & 296 & --- \\
\hline $\mathrm{LSD}_{0.05}$ & NS & $5.6^{* * * *}$ & $0.5^{* * *}$ & NS & NS & NS & --- \\
\hline \multicolumn{8}{|c|}{ 1998-99 } \\
\hline NuMex Chaco & 25 May & 0.5 & 2.3 & 92 & 98.7 & 460 & 78.1 \\
\hline Daybreak & 25 May & 14.4 & 2.2 & 87 & 79.4 & 448 & 50.3 \\
\hline Ibex & 24 May & 0.8 & 3.1 & 89 & 95.8 & 429 & 43.7 \\
\hline NuMex Mesa & 25 May & 1.2 & 2.3 & 83 & 82.4 & 487 & 59.6 \\
\hline Mean & 24 May & 4.2 & 2.5 & 88 & 89.1 & 456 & 57.9 \\
\hline $\mathrm{LSD}_{0.05}$ & NS & $6.4^{* *}$ & NS & NS & NS & NS & $18.2^{*}$ \\
\hline \multicolumn{8}{|c|}{ 1999-2000 } \\
\hline NuMex Chaco & 17 May & 0.5 & 2.0 & 92 & 71.8 & 392 & 85.0 \\
\hline Daybreak & 18 May & 15.7 & 1.7 & 93 & 65.2 & 427 & 37.0 \\
\hline Ibex & 18 May & 2.0 & 1.8 & 89 & 65.3 & 372 & 37.0 \\
\hline NuMex Mesa & 17 May & 1.5 & 1.9 & 94 & 83.8 & 442 & 57.0 \\
\hline Mean & 17 May & 4.9 & 1.9 & 92 & 71.6 & 408 & 54.0 \\
\hline $\mathrm{LSD}_{0.05}$ & NS & $6.4^{* *}$ & NS & NS & $14.6^{*}$ & NS & $11.1^{* * * *}$ \\
\hline
\end{tabular}

${ }^{\mathrm{z}} \mathrm{A}$ plot was considered matured when at least $80 \%$ of the plant tops were down.

yThe percentage of seedstalks was determined at harvest and calculated by dividing the number of plants with

xPink root rating. Root system of bulbs were rated based upon a rating scale of 1 (no infected roots) to 9

wercentage of marketable yield was calculated by dividing marketable bulb weight by total bulb weight. ${ }^{\mathrm{v}}$ Marketable yield $\left(\mathrm{t} \cdot \mathrm{ha}^{-1}\right.$ ) was calculated by weighing the marketable bulbs per plot and adjusting the plot

"Bulb weight was calculated by dividing the marketable bulb weight by the number of marketable bulbs. 'The percentage of bulbs with single centers (single growing point) was determined by cutting each bulb transversely at the vertical center and measuring the number of growing points that extended $1.3 \mathrm{~cm}$ beyond

ss, ******** Nonsignificant or significant at $P=0.05,0.01$, or 0.001 , respectively. 
bulbs of the same size to possess the same desired shape. Selection for bulb scale color was based on the color of the dry outer bulb scales. Selection for bulb or scale color was for a color that was darker yellow than 'Texas Early Grano 502 PRR BR'. Selection for bulb shape and color was subjective, based on visual observation. Selection for bulb firmness was based on a subjective evaluation of the amount of bulb scale resistance when a force was applied to the bulb. Selection for bulb maturity was to select bulbs that matured the last week of May. Selection for a single growing point per bulb was accomplished by transversely cutting selected bulbs at the vertical center of each bulb. Bulbs with a single growing point or multiple growing points within $1.3 \mathrm{~cm}$ from the center of the bulb were selected and advanced to the next cycle by planting the bottom half of the bulb.

\section{Description and performance}

'NuMex Chaco' is a short-day, open-pollinated, grano-type onion that matures from 20 May to 30 May when fall-seeded in Las
Cruces, N.M. Suggested planting dates at Las Cruces are 20 Sept. to 1 Oct. 'NuMex Chaco' has excellent yield, firmness, pink root resistance, bolting resistance, a high percentage of single-centered bulbs, round to slightly top-shaped bulbs, good scale quality, and early maturity, similar to 'NuMex Mesa'. 'NuMex Chaco' produces a higher percentage of single-centered bulbs than any other cultivar in its maturity class (Table 1). 'NuMex Chaco' is recommended for fall-seeding to provide a harvest of highly single-centered bulbs for ring processing or fresh market during late May.

Replicated field trials were conducted in 1997-98, 1998-99, and 1999-2000 comparing 'NuMex Chaco' to 'Daybreak', 'Ibex', and 'NuMex Mesa' (Table 1). 'NuMex Chaco' produced a higher percentage of single centered bulbs than 'Daybreak', 'Ibex', or 'NuMex Mesa'. For onion ring processing, $75 \%$ or greater single-centered bulbs is desirable. 'NuMex Chaco' produced fewer seedstalks than 'Daybreak' (Table 1). 'NuMex Chaco' was comparable to 'Daybreak', 'Ibex', and 'NuMex Mesa' for maturity date, per- centage marketable yield, marketable sacks per acre, and average bulb weight (Table 1).

\section{Availability}

Currently, 'NuMex Chaco' is being produced, marketed, and sold exclusively by Lockhart Seed Co., Stockton, Calif. Plant Variety Protection certificate number 200000352 has been issued.

\section{Literature Cited}

Corgan, J.N. 1984. 'NuMex BR 1' onion. HortScience 19:593.

Garcia, F. and A.B. Fite. 1931. Early grano onion culture. N.M. Agr. Expt. Sta. Bul. 193.

Havey, M.J. and O.H. Bark. 1994. Molecular confirmation that sterile cytoplasm has been introduced into open-pollinated grano onion cultivars. J. Amer. Soc. Hort. Sci. 119:90-93.

Hawthorn, L.R. 1944. Texas grano onion. Texas Agr. Expt. Sta. Prog. Rpt. 899.

Magruder, R., R.E. Webster, H.A. Jones, T.E Randall, G.B. Snyder, H.D. Brown, L.R. Hawthorn, and A.L. Wilson. 1941. Descriptions of types of principal American varieties of onions. U.S. Dept. Agr. Misc. Publ. 435. 